\title{
ANALISIS PENGHINDARAN RISIKO PADA KEPUTUSAN INVESTASI DI PASAR MODAL INDONESIA
}

\section{RISK AVERSION ANALYSIS OF INVESTMENT DECISIONS IN INDONESIAN CAPITAL MARKET}

\author{
Tazkiyah Sakinah $^{* 1}$, Budi Purwanto*), dan Wita Juwita Ermawati*) \\ *) Departemen Manajemen, Fakultas Ekonomi dan Manajemen, IPB University \\ Jl. Agatis, Kampus IPB Dramaga Bogor 16680, Indonesia
}

\begin{abstract}
Decision making in the capital market is not always rational. It is due to the emotional involvement of investors, which is described through financial behavior. Investor decision making based on financial behavior is considered as a loss aversion contained in prospect theory. In this theory, the prospect of risk aversion behavior when the market is profitable, but this behavior becomes an obstacle for investors to get higher returns. This study aimed to analyze the risk avoidance behavior that limits investment decision making in Indonesian stock investors. Primary data were obtained from individual investor transactions on the IDX, and secondary data were in the form of daily stock data. Identification of risk aversion was carried out using a non-linear regression method. The measurement of psychological resistance was carried out through an independent sample t-test by measuring the difference between actual and expected returns. The results showed that Indonesia's capital market investors have a riskaverse behavior in the gain domain and risk-seeking in the loss domain. Risk-averse behavior could reduce investment productivity.
\end{abstract}

Keywords: behavioral finance, decision-making, prospect theory, return, risk averse

\begin{abstract}
Abstrak: Pengambilan keputusan pada pasar modal tidak selalu rasional. Hal ini dikarenakan keterlibatan emosi investor yang digambarkan melalui perilaku keuangan. Pengambilan keputusan investor berdasarkan perilaku keuangan diasumsikan bersifat loss aversion yang terdapat dalam teori prospek. Menurut teori prospek, perilaku penghindaran risiko terjadi ketika pasar tengah berada pada situasi menguntungkan, namun investor oleh karena perilaku tersebut justru menghadapi kendala untuk memeroleh laba yang lebih tinggi. Penelitian ini bertujuan untuk menganalisis perilaku penghindaran risiko yang membatasi pengambilan keputusan investasi pada investor saham Indonesia. Pengumpulan data primer diperoleh dari transaksi investor individu di BEI dan data sekunder berupa data saham harian. Identifikasi penghindaran risiko dilakukan dengan metode regresi non-linear serta pengukuran hambatan psikologis dilakukan melalui independent sample $t$ test dengan mengukur perbedaan pengembalian aktual dan pengembalian yang diharapkan. Hasil penelitian menunjukkan bahwa investor pasar modal di Indonesia memiliki perilaku risk averse pada kondisi untung dan risk seeker pada kondisi rugi. Perilaku risk averse dapat mengurangi produktivitas investasi.
\end{abstract}

Kata kunci: perilaku keuangan, pengambilan keputusan, teori prospek, pengembalian, penghindaran risiko

\footnotetext{
${ }^{1}$ Corresponding author:

Email: tazkiyah_sakinah@apps.ipb.ac.id
} 


\section{PENDAHULUAN}

Keputusan investasi dalam pasar modal memiliki tingkat risiko tertentu. Peningkatan nilai yang dihasilkan dari berinvestasi menjadi tujuan investor untuk menanamkan asetnya pada pasar modal, namun investasi tersebut tidak menjamin adanya keuntungan. Secara teori, tingkat pengembalian atas investasi atau return yang tinggi memiliki tingkat risiko yang tinggi sehingga terjadi korelasi positif antara pengembalian dan risiko (Bodie et al. 2018). Hal ini menjadi perhatian investor untuk mengurangi risiko investasi dalam menentukan keputusan terbaik.

Secara empiris, investor tidak selalu rasional atau menggunakan model kuantitatif yang sama dalam proses pengambilan keputusan. Investor irasional akan melibatkan emosi yang ditandai dengan ketakutan terhadap kondisi yang tidak pasti (Al-Dahan et al. 2019; Zahera dan Bansal, 2018; Lee dan Andrade, 2015) sehingga pengambilan keputusan melibatkan sikap risiko individu pada perilaku keuangan (Robiyanto dan Puryandani, 2015). Keputusan investasi didasari oleh pemahaman investor dari informasi yang berkaitan dengan investasinya, namun informasi pasar yang beredar dapat dipahami berbeda oleh setiap investor. Pemahaman terkait informasi yang berbeda memungkinkan terjadi bias dalam mengambil keputusan, hal ini disebut sebagai perilaku keuangan atau behavioral finance. Perilaku berinvetasi tidak selalu rasional dan kondisi pasar tidak selalu efisien sehingga investor akan menunjukkan kesalahan kognitif yang berkaitan dengan emosi dalam proses pengambilan keputusan (Raut dan Kumar, 2018; Kapoora dan Prosad, 2017). Oleh karena itu, pengambilan keputusan investasi yang melibatkan faktor psikologis berperan pada kinerja portofolio investor serta pada perilaku pasar yang dapat membentuk beberapa anomali pasar.

Pengambilan keputusan investor berdasarkan perilaku keuangan diasumsikan bersifat loss aversion. Salah satu konsep perilaku keuangan ini mengacu pada penilaian investor dalam menghindari pasar yang sedang mengalami kerugian. Loss aversion merupakan efek dari utilitas kerugian yang jauh lebih besar daripada keuntungan dengan ukuran yang sama, hal ini dijelaskan dalam teori prospek (Hofmeyr dan Kincaid, 2018; Lewandowski, 2017; Kahnemann dan Tversky, 1979). Teori prospek atau prospect theory menjelaskan bahwa seseorang yang mengambil keputusan dihadapkan pada kondisi yang tidak pasti dalam menentukan pilihan, hal ini tidak lepas dari kondisi yang menguntungkan atau merugikan. Ketika pasar sedang mengalami kondisi untung, investor cenderung tidak bersedia menerima risiko jika suatu saat terjadi kerugian dengan menjual sahamnya sehingga akan berperilaku menghindari risiko atau risk averse. Sebaliknya, ketika pasar sedang mengalami kondisi rugi, investor akan bersedia menanggung risiko dengan menahan penjualan saham sehingga investor akan berperilaku risk seeker.

Perilaku penghindaran risiko dapat menjadi hambatan psikologis seorang investor karena akan membatasi perolehan pengembalian atas investasi. Menurut Ilut dan Schneider (2014) investor dihadapkan dengan berbagai kemungkinan hasil yang seolah-olah hasil buruk terjadi sehingga beranggapan bahwa investor memiliki keyakinan yang pesimis. Penghindaran risiko atau risk averse dalam pasar modal menjadi perilaku yang perlu diantisipasi karena dapat membatasi investor dalam memeroleh pengembalian yang lebih tinggi. Perilaku penghindaran risiko yang tinggi akan memiliki proporsi aset yang lebih rendah, begitupun proporsi aset yang tinggi memiliki perilaku penghindaran risiko yang rendah (Mahdzan et al. 2017; Grable dan Carr, 2014). Hal ini mengindikasikan bahwa perilaku penghindaran risiko dapat mengabaikan peluang untuk mendapatkan pengembalian atau hasil investasi yang lebih tinggi.

Pengambilan keputusan investasi yang ada di Indonesia menjadi salah satu perhatian terutama di Asia Tenggara. Indonesia memeroleh jumlah frekuensi transaksi harian saham tertinggi di kawasan ASEAN pada tahun 2018 dengan nilai rata-rata 387 ribu transaksi perhari (BEI, 2019). Data Statistik BEI (2020) juga menunjukkan peningkatan sebesar 9\% total nilai perdagangan saham tahun 2019 dibandingkan tahun 2018, sehingga Indonesia memiliki perkembangan kinerja pasar modal yang baik. Namun kontribusi investor domestik dalam nilai perdagangan ini memiliki nilai beli yang lebih rendah dari nilai jualnya, sehingga hal tersebut dimanfaatkan oleh investor asing untuk mendapatkan nilai beli yang lebih tinggi (Gambar 1). Hal ini salah satunya disebabkan oleh kondisi indeks harga saham gabungan 2019 yang mengalami kenaikan dari tahun sebelumnya sebesar 1,7\%. Kondisi ini juga terlihat pada tahun 2016 yaitu ketika IHSG naik akan meningkatkan penjualan saham oleh investor domestik. Berbeda saat kondisi pasar melemah pada tahun 2015 dan 2018, tingkat pembelian saham oleh investor domestik 
lebih tinggi dibandingkan investor asing ketika IHSG menurun. Peningkatan IHSG tidak hanya dimaknai dengan dampak baik, namun peningkatan ini menjadi peluang investor untuk melepaskan investasinya dan menghindar dari risiko untuk sebagian investor. Pelepasan aset yang dilakukan mengakibatkan investor memeroleh keuntungan di bawah nilai ekspektasi (opportunityloss) karena terlalu cepat mengambil untung. Pengambilan keputusan investasi oleh pelaku saham Indonesia mengindikasikan terjadinya loss aversion dan penghindaran risiko di pasar modal sehingga mendukung literatur yang telah diungkapkan penelitian terdahulu.

Pelaku investasi cenderung menghindar risiko pada kondisi untung. Perilaku penghindaran risiko berpotensi menjadi penghambat untuk meningkatkan produktivitas investasi disebabkan adanya korelasi yang berlawanan dengan harga aset (Diaz dan Esparcia, 2019). Investor dalam meningkatkan produktivitas investasi membutuhkan pertimbangan dalam melakukan pengambilan keputusan sehingga perilaku penghindaran risiko saat kondisi untung menjadi keputusan yang salah. Penelitian ini bertujuan untuk menganalisis hambatan pengambilan keputusan investasi pada pelaku saham Indonesia akibat penghindaran risiko investasi melalui identifikasi loss aversion yang dikembangkan Kahnemann dan Tversky (1979). Penelitian ini terfokus pada perilaku investor individu saham di pasar modal Indonesia dengan keputusan investasi yang digambarkan dengan menahan atau menjual saham sehingga memeroleh nilai return yang digunakan dalam analisis penghindaran risiko.

\section{METODE PENELITIAN}

Penelitian ini menggunakan data primer dan sekunder. Data primer diperoleh dari investor saham individu pasar modal Indonesia yang diperoleh dari penyebaran kuesioner secara langsung dan melalui formulir online. Data transaksi saham yang diperlukan minimal satu tahun terakhir untuk menghindari hasil yang bias dan mendapatkan rata-rata yang lebih robust. Penyebaran kuesioner ini dilakukan pada bulan Februari sampai bulan Maret 2020. Data sekunder yang digunakan berupa harga saham harian dan literatur lainnya yang relevan dari instansi yang berkaitan.

Metode penarikan sampel yang digunakan dalam penelitian ini yaitu non-probability sampling dengan teknik convenience sampling. Teknik convenience sampling merupakan teknik yang paling mudah dalam penarikan sampel dengan menarik siapa saja yang memenuhi karakteristik responden pada suatu observasi (Hakim, 2010). Jumlah sampel pada penelitian ini sebanyak 100 responden yang ditentukan menggunakan teori Slovin (Sugiyono, 2011) dengan tingkat toleransi $10 \%$. Jumlah sampel dengan minimum 30 responden, distribusi sampling dari rata-rata sampel akan mendekati distribusi normal apapun bentuk awal distribusinya (Campbell, 2019; Lancaster et al. 2014).

Metode analisis data dalam penelitian ini yaitu analisis regresi non-linear dan analisis beda dua grup. Analisis regresi non-linear digunakan untuk menunjukkan fenomena loss aversion yang dipostulatkan dalam teori prospek melalui fungsi nilai $S$-shape (Lewandowski 2017). Sebelum dilakukan analisis regresi non-linear, diperlukan perhitungan return aktual saham investor yang dihitung menggunakan data harian dengan basis harga kepemilikan saham periode sebelumnya (return basis aktiva bersih) dan basis harga pembelian saham (return basis beli). Hasil dari return tersebut akan klasifikasikan ke dalam fungsi nilai keuntungan dan kerugian dengan persamaan berikut.

$$
u(x)=\left\{\begin{aligned}
x^{\alpha}, & x \geq 0 \\
-\lambda(-x)^{\beta}, & x<0
\end{aligned}\right.
$$

Fungsi nilai $S$-shape ini menjelaskan fungsi nilai keuntungan yang digambarkan dengan kurva cekung dan fungsi nilai kerugian yang digambarkan kurva cembung dengan kondisi yang lebih curam dari keuntungan (Gambar 2).

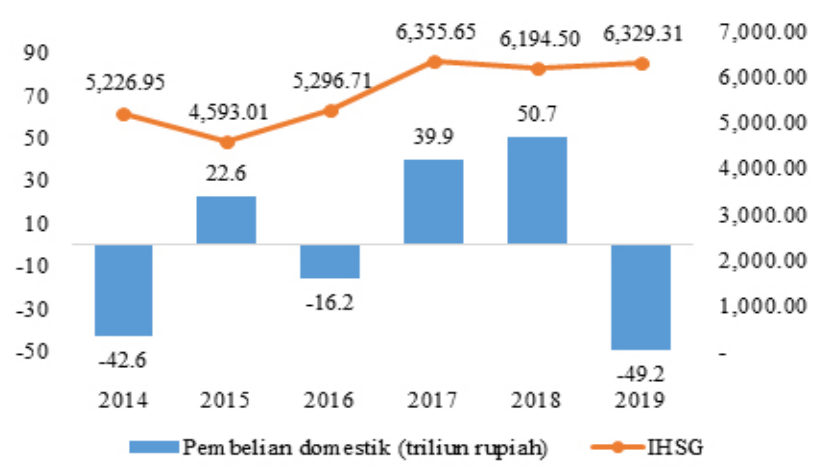

Gambar 1. Net pembelian saham investor domestik (BEI, 2020) 


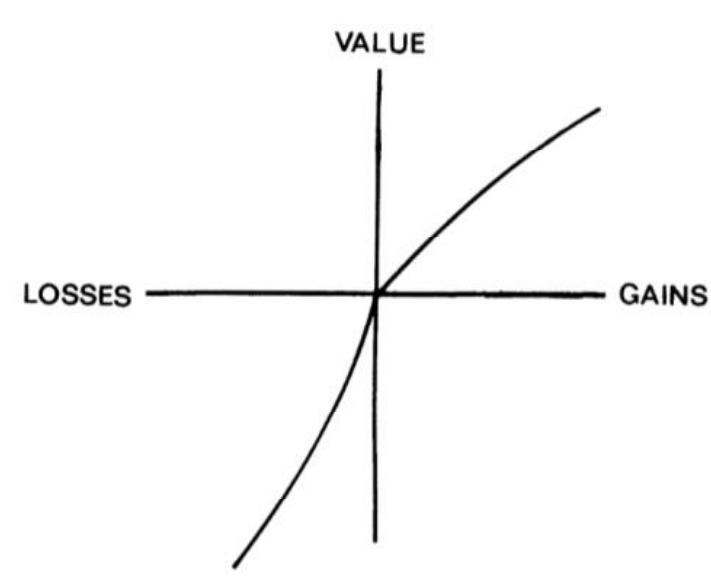

Gambar 2. Fungsi Nilai Prospect Theory (Kahneman dan Tversky, 1979)

Analisis beda dua kelompok menggunakan independent sample t-test. Menurut Pallant (2010), independent sample t-test merupakan uji parametrik yang menggunakan dua kelompok atau dua set data yang tidak saling berpasangan untuk menemukan dampak perbedaan model yang diterapkan dalam suatu gugus data. Pada pengujian ini, dua kelompok data yang dilihat perbedaan variasinya yaitu return aktual investor (yang sudah terjadi) dan expected return atau return yang masih menjadi nilai harapan yang terjadi pada periode mendatang (Bodie et al. 2018). Perbandingan antara actual return dan expected return ini mengindikasikan adanya peluang return untuk seorang investor sehingga diharapkan dapat menjawab hambatan dari risk averse.

Penelitian ini membentuk kerangka pemikiran yang diawali dengan keputusan investasi yang digambarkan dengan menahan atau menjual saham sehingga memeroleh nilai return. Perolehan return yang dilakukan akan dianalisis menghasilkan perilaku pelaku saham berupa risk seeker dan risk averse. Kedua risiko yang terbentuk dihipotesiskan akan memiliki fenomena loss aversion dalam teori prospek. Penghindaran risiko berdasarkan hasil teori prospek mengindikasikan hambatan psikologis pada pelaku saham. Kerangka pemikiran dalam penelitian ini dapat dilihat pada Gambar 3.

Keputusan investasi saham didasarkan pada transaksi atau perdagangan saham berupa penjualan, pembelian, atau menahan saham (Sobolev et al. 2017). Pada kondisi pasar yang berbeda yaitu kondisi rugi dan untung, investor akan mengalami ketidakpastian dalam menentukan keputusannya karena bergantung pada risiko yang dihasilkan dari masing-masing kondisi.
Investor mengalokasikan aset tertentu dengan harapan mendapatkan manfaat yang dirasakan pada waktu yang akan datang (Rasheed et al. 2018). Dampak utilitas dari kerugian lebih besar dari keuntungan dengan ukuran nilai yang sama atau disebut juga loss aversion (Kahneman dan Tversky, 1979). Seorang investor akan menghindar risiko atau risk averse pada kondisi untung dengan menjual saham. Sedangkan dalam kondisi rugi, perilaku investor akan menahan risiko atau risk seeker dengan menahan penjualan saham sehingga bersedia untuk menanggung risiko dikemudian hari (Arkes et al. 2010; Tversky dan Kahneman, 1992).

Investor yang memiliki perilaku penghindaran risiko yang tinggi akan memiliki proporsi aset berisiko yang lebih rendah (Mahdzan et al. 2017; Grable dan Carr, 2014). Perilaku penghindaran risiko dapat ini berpotensi untuk mengabaikan peluang mendapatkan return yang lebih tinggi. Investasi yang produktif mengambil tingkat risiko yang tinggi, sehingga Sauner dan Leroy (2004) menunjukkan hasil bahwa terdapat korelasi yang negatif antara penghindaran risiko dengan produktivitas investasi. Hal ini didukung dengan Diaz dan Esparcia (2019) bahwa penghindaran risiko berlawanan dengan penetapan harga aset sehingga ketakutan investor terhadap ketidakpastian dapat membatasi perolehan return yang lebih tinggi.

H1 : Investor pasar modal Indonesia akan berperilaku sebagai risk seeker saat mengalami kerugian pada return

$\mathrm{H} 2$ : Investor pasar modal Indonesia akan berperilaku sebagai risk averse saat mengalami keuntungan pada return

H3 : Investor pasar modal Indonesia bersifat loss aversion

H4 : Perilaku risk averse membatasi peningkatan return investor

\section{HASIL}

\section{Pengujian Fungsi Nilai dalam Prospek Teori}

Pengukuran loss aversion dalam menggambarkan perilaku keuangan investor individu di Indonesia dilakukan pengujian fungsi nilai keuntungan dan kerugian atau pengujian hypothetical value function (Kahneman dan Tversky, 1979). Hypothetical value function disajikan melalui analisis regresi non-linear dengan return aktual pada sumbu $\mathrm{x}$ dan return value 
pada sumbu y. Analisis regresi non-linear berdasarkan fungsi nilai tanpa menggunakan intersep dimodelkan sebagai berikut.

$$
\begin{array}{lll}
R V_{\text {gain }}=\gamma\left(R_{\text {gain }}\right)^{\alpha}+\varepsilon_{i} & x \geq 0 \\
R V_{\text {loss }}=-\lambda\left(-R_{\text {loss }}\right)^{\beta}+\varepsilon_{j} & x<0
\end{array}
$$

Jumlah responden yang dikumpulkan sebanyak 102 investor individu, didapatkan sebanyak 536 data transaksi saham yang dilakukan minimal satu tahun terakhir. Hasil transaksi tersebut dilakukan cleaning data sehingga menghasilkan 482 data transaksi yang terpakai untuk dimasukkan ke dalam pengujian karena kurangnya informasi untuk menentukan nilai pengembalian aktual. Dari hasil cleaning data tersebut, terdiri dari 206 data penjualan saham dan 276 data saham yang ditahan serta jumlah data nilai untung dan nilai rugi dari hasil pengembalian. Return berdasarkan aktiva bersih mendapatkan data bernilai positif sebanyak 230 transaksi dan 252 data transaksi bernilai negatif. Jika berdasarkan pembelian, terdapat 235 transaksi bernilai positif dan 247 transaksi bernilai negatif.

Untuk menguji hipotesis 1 dan 2, fungsi nilai teori prospek diasumsikan memiliki nilai $\alpha$ dan $\beta$ kurang dari 1 dan sama besar. Berdasarkan pengujian regresi nonlinear menghasilkan nilai $\alpha$ dan $\beta$ sebesar 0,9 dengan return basis pembelian serta nilai $\alpha$ dan $\beta$ sebesar 0,85 dengan return basis aktiva bersih. Nilai yang dihasilkan memiliki nilai kurang dari 1 dan mendekati nilai estimasi Tversky dan Kahneman (1992) yaitu sebesar 0,88, kemudian hasil penelitian Arkes et al. (2010) dengan nilai 0,84 pada negara Amerika dan 0,93 pada negara Asia, serta Fauziah (2019) yang memeroleh nilai 0,7 pada investor pemula Indonesia.

Nilai $\alpha$ kurang dari 1 menunjukkan bahwa kurva dalam kondisi untung berbentuk cekung yang mengindikasikan investor pasar modal Indonesia memiliki perilaku penghindaran risiko atau risk averse ketika memeroleh keuntungan pada return. Begitu pula nilai $\beta$ yang menghasilkan nilai kurang dari 1 bahwa adanya perilaku menahan risiko atau risk seeker saat return dalam kondisi rugi dan menggambarkan kurva cembung. Hasil tersebut telah sesuai dengan teori prospek yaitu berbentuk cekung saat kondisi gain dan cembung untuk kondisi loss. Parameter fungsi nilai yang dihasilkan dari regresi non-linear terlihat pada Tabel 1.
Penyajian kurva yang menggambarkan hypothetical value function dengan return berbasis pembelian ditunjukkan pada Gambar 3 serta return berbasis aktiva bersih ditunjukkan pada Gambar 4.

Tabel 1. Hasil pengujian regresi non-linear

\begin{tabular}{llcc}
\hline $\begin{array}{l}\text { Model } \\
\text { Summary }\end{array}$ & Syarat & $\begin{array}{c}\text { Return basis } \\
\text { beli }\end{array}$ & $\begin{array}{c}\text { Return } \\
\text { aktiva bersih }\end{array}$ \\
\hline$\alpha$ & $\alpha<1$ & 0,9 & 0,85 \\
$\beta$ & $\beta<1$ & 0,9 & 0,85 \\
$\gamma$ & $\gamma=1$ & 1,24 & 0.84 \\
$\lambda$ & $\lambda>1$ & 1,01 & 0.72 \\
R-Square & & 0,99 & 0,98 \\
\hline
\end{tabular}

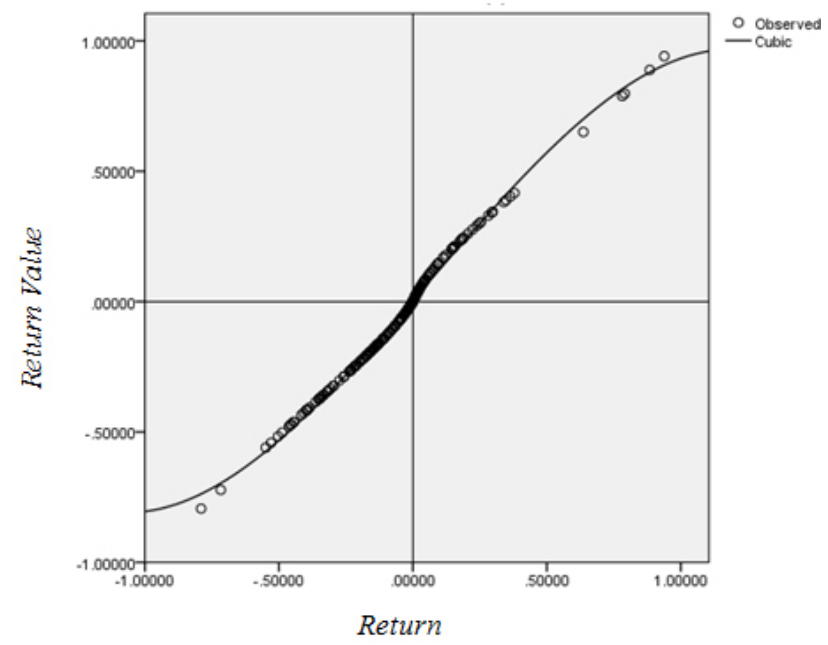

Gambar 3. Kurva fungsi nilai terhadap return basis beli

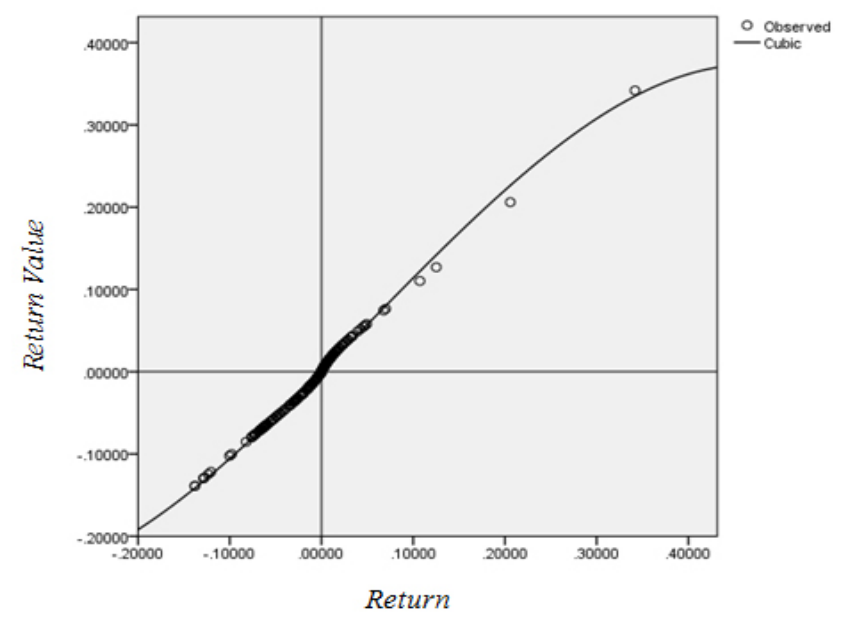

Gambar 4. Kurva fungsi nilai terhadap return basis aktiva bersih 
Penggunaan return yang berbasis pembelian dan aktiva bersih menggambarkan hasil yang sama dalam penyajian kurva yang sesuai dengan teori prospek yaitu cekung pada kondisi untung dan cembung pada kondisi rugi. Responden yang terdiri beragam karakteristik investor pada pasar modal di Indonesia memiliki berbagai analisis, seperti analisis fundamental, teknikal, maupun ekonomi makro yang menjadi pertimbangan dalam menentukan keputusan investasinya. Hal ini menjadikan kedua nilai pengembalian tersebut memiliki pengaruh yang sama dalam dua kondisi yang berbeda. Sumber penghasilan seorang investor akan berpengaruh kepada penggunaannya (Thaler, 1999), sehingga return yang telah terakumulasi dari pembelian dan return akibat perubahan harga harian akan berpengaruh terhadap keputusan investasi sesuai dengan value yang didapatkan.

Fenomena loss aversion pada teori prospek ditunjukkan oleh koefisien $\lambda>1$ dengan nilai $\gamma$ tidak berbeda signifikan dari 1 dan dan diasumsikan $\alpha=\beta$. Hasil yang diperoleh dari pengujian bahwa investor pada pasar modal Indonesia tidak bersifat loss aversion. Berdasarkan regresi return basis beli, koefisien fungsi nilai positif memiliki nilai lebih dari 1 sehingga tidak memenuhi syarat fungsi nilai utilitas meskipun nilai koefisien fungsi negatif menghasilkan $\lambda$ lebih dari 1 . Sama halnya regresi return basis aktiva bersih yang belum dapat menjelaskan adanya loss aversion pada investor pasar modal Indonesia. Hasil regresi tersebut menunjukkan nilai $\gamma$ yang berbeda dari nilai 1 dan nilai $\lambda$ kurang dari 1 (Tabel 3). Pengujian yang dihasilkan tidak sesuai dengan nilai estimasi $\lambda$ oleh Tversky dan Kahneman (1992) yaitu sebesar 2,25 serta Arkes et al. (2010) yang menghasilkan nilai 1,86 di Amerika dan 1,66 di Asia.

Nilai koefisien yang dihasilkan menunjukkan nilai utilitas pada keuntungan lebih besar daripada nilai kerugian dengan ukuran eksponensial yang sama. Hasil loss aversion yang tidak terjadi tidak mendukung hasil Liu et al. (2014) yaitu trader melalui online financing trading memiliki penghindaran terhadap kerugian sehingga cenderung menghindari risiko dan akan cepat menutup posisinya dengan mengambil keuntungan yang sedikit. Perbedaan dari nilai utilitas keuntungan dan kerugian disebabkan adanya proses hedonis yang mendasar. Nilai keuntungan yang lebih besar mendorong adanya adaptasi yang lebih cepat pada manfaat hedonisme dengan pemisahan keuntungan dan integrasi kerugian antar waktu (Arkes et al. 2010; Thaler, 1999). Adaptasi yang lebih cepat dapat dikaitkan dengan loss aversion yang tidak terjadi atau memiliki nilai yang rendah mendorong peningkatan adaptasi terhadap utilitas hedonis. Loss aversion yang tidak terjadi karena adanya pemisahan terhadap kerugian sebelumnya sehingga kerugian saat ini tidak terlalu menyakitkan. Pembingkaian hedonis dijelaskan dalam fenomena mental accounting menurut Thaler (1999). Oleh karena itu perilaku keuangan memiliki keterkaitan terhadap perilaku konsumsi pada masyarakat (Amaiyah dan Ismanto, 2020).

Hasil pengujian dalam menguji fungsi nilai yang telah dipostulatkan oleh Tversky dan Kahneman (1992) melalui regresi non-linear menunjukkan hasil yang kurang sesuai dengan asumsi cumulative prospect theory. Perilaku menghindari risiko atau risk averse dan menahan risiko atau risk seeker terdeteksi pada investor pasar modal di Indonesia. Namun perilaku yang dihasilkan tersebut tidak dapat menjelaskan penghindaran kerugian atau loss aversion pada cumulative prospect theory.

\section{Analisis Beda Dua Kelompok}

Investor individu di Bursa Efek Indonesia memiliki perilaku penghindaran risiko yang telah dibuktikan pada pembahasan sebelumnya. Perilaku penghindaran risiko tersebut berpotensi mengabaikan peluang mendapatkan nilai pengembalian yang lebih tinggi. Untuk membuktikan perilaku penghindaran risiko menjadi hambatan dalam berinvestasi, penelitian ini menguji perbedaan hasil return aktual dan return yang diharapkan menggunakan uji $\mathrm{t}$ dua sampel tidak berpasangan yang disajikan dalam Tabel 2 .

Hasil pengujian independent sampel test yang disajikan dalam Tabel 2 menunjukkan bahwa nilai pengembalian aktual berbasis aktiva bersih dan beli berbeda signifikan pada taraf 5\% terhadap nilai pengembalian yang diharapkan. Terlihat dari nilai p-value return basis beli vs expected return dan return basis aktiva bersih vs expected return pada taraf $95 \%$ masing-masing sebesar 0,02 dan 0,035. Kedua nilai p-value lebih kecil dari 0,05 sehingga actual return dan expected return signifikan berbeda nyata. Perbedaan pada actual return dan expected return memiliki nilai rataan ragam yang berbeda dan menunjukkan nilai yang negatif baik actual return berbasis pembelian maupun aktiva bersih. Nilai actual return yang berbeda dengan expected return menjadi hambatan investor untuk memeroleh pengembalian yang lebih tinggi. 


\begin{tabular}{llll}
\hline & $95 \%$ CI for difference & t-hitung & P-value \\
\hline Actual Return (Return basis beli) vs Expected Return & $(-.08382348,-.01996020)$ & $-3,194$ & 0,02 \\
Actual Return (Return basis aktiva bersih) vs Expected Return & $(-.01433695,-.00051913)$ & $-2,113$ & 0,035 \\
\hline
\end{tabular}

Hubungan antara penghindaran risiko dan produktivitas investasi yang digambarkan melalui return yang diterima dan return yang diharapkan cukup membuktikan Hipotesis 4 bahwa perilaku risk averse membatasi perolehan return. Hasil penelitian ini mendukung Sauner dan Leroy (2004) bahwa terjadi korelasi negatif antara penghindaran risiko douiengan produktivitas investasi. Korelasi yang terjadi membuktikan bahwa penghindaran risiko yang tinggi memiliki proporsi aset berisiko yang lebih tinggi sehingga dapat meningkatkan kepercayaan diri atas investasinya (Mahdzan et al. 2017).

\section{Implikasi Manajerial}

Penghindaran terhadap risiko investasi terjadi ketika nilai pengembalian investasi dalam kondisi untung. Perilaku tersebut dapat menjadi hambatan dalam pengambilan keputusan karena berpotensi mengurangi peningkatan return. Hal ini telah terbukti bahwa penghindaran risiko yang tinggi akan mengurangi produktivitas investasinya. Investor dalam meningkatkan produktivitas investasi dibutuhkan pertimbangan dalam melakukan pengambilan keputusan dalam dua kondisi nilai pengembalian.

Dalam kondisi untung, investor individu sebaiknya jangan terlalu terburu-buru dalam menjual sahamnya karena terdapat kemungkinan memeroleh return yang lebih tinggi pada masa yang akan datang. Namun penahanan saham yang terlalu lama juga tidak menjanjikan perolehan return yang sangat tinggi karena banyak faktor-faktor lainnya yang menyebabkan harga akan turun pula. Penentuan penghindaran risiko yang tepat dibutuhkan adanya analisis valuasi saham dengan analisis tertentu. Beberapa analisis tersebut berupa analisis fundamental, analisis teknikal atau analisis ekonomi makro. Oleh karena itu, penentuan penghindaran risiko yang tepat memerlukan literasi pasar modal yang baik.

\section{KESIMPULAN DAN SARAN}

\section{Kesimpulan}

Hasil penelitian ini mengungkapkan bahwa investor pasar modal di Indonesia memiliki perilaku yang sesuai dengan fungsi nilai teori prospek pada kedua dasar nilai pengembalian. Investor pasar modal di Indonesia memiliki perilaku risk averse pada kondisi untung sehingga fungsi nilai keuntungan berbentuk cekung. Pada kondisi rugi, perilaku investor diasumsikan risk seeker sehingga fungsi nilai kerugian berbentuk cembung. Namun teori prospek yang mengasumsikan keputusan investasi bersifat loss aversion tidak terjadi pada investor pasar modal di Indonesia sehingga tidak menunjukkan hasil yang sesuai dengan asumsi teori prospek. Loss aversion yang tidak terjadi karena adanya pemisahan terhadap kerugian sebelumnya sehingga kerugian saat ini tidak terlalu menyakitkan. Penghindaran kerugian atau risk averse yang terjadi berpotensi mengurangi peluang mendapatkan return yang lebih tinggi. Hasil pengujian independent sampel test membuktikan bahwa adanya perbedaan terbalik yang signifikan antara actual return dan expected return sehingga terjadi korelasi negatif antara penghindaran risiko dengan produktivitas investasi.

\section{Saran}

Hasil penelitian membuktikan bahwa perilaku penghindaran risiko dapat membatasi produktivitas dalam pengambilan keputusan investasi. Namun, faktorfaktor yang dapat menyebabkan perilaku penghindaran risiko belum terungkap. Selain itu, penelitian ini tidak membuktikan adanya loss aversion karena diasumsikan adanya adaptasi yang lebih cepat dalam merespon manfaat hedonisme. Penelitian selanjutnya diharapkan melakukan pengujian perilaku hedonisme pada investor Indonesia dan menganalisa faktor-faktor yang menyebabkan perilaku penghindaran risiko sehingga keputusan investasi yang dilakukan tepat serta meningkatkan produktivitas investasi. 


\section{DAFTAR PUSTAKA}

[BEI] Bursa Efek Indonesia. 2019. Press Release Detail : BEI Optimis Pasar Modal Indonesia Tetap Tumbuh Positif. www.idx.co.id. [27 Nov 2019].

[BEI] Bursa Efek Indonesia. 2020. IDX Statistics 2019. www.idx.co.id. [30 Jan 2020].

Al-Dahan NSH, Hasan MF, Jadah HM. 2019. Effect of cognitive and emotional biases on investor decisions: An analytical study of the iraq stock exchange. International Journal of Innovation, Creativity and Change 9(10) : 30-47.

Amaiyah NI, Ismanto H. 2020. Literasi keuangan dan perilaku keuangan karyawan swasta di kabupaten jepara. Jurnal Aplikasi Manajemen dan Bisnis 6(3): $\quad 468-477 . \quad$ https://doi.org/10.17358/ jabm.6.3.468.

Arkes HR, Hirshleifer D, Jiang D, Lim S. 2010. A crosscultural study of reference point adaptation: Evidence from China, Korea, and the US. Organizational Behavior and Human Decision Processes 112: 99-111. https://doi.org/10.1016/j. obhdp.2010.02.002.

Bodie, Kane, Marcus. 2018. Investments. Ed. ke-8. New York : McGraw-Hill Education.

Campbell M. 2019. Sample size: methods of calculation and reporting. African Journal Of Midwifery and Women's Health 13(2): 1-9. https://doi. org/10.12968/AJMW.2019.0007.

Diaz A dan Esparcia C. 2019. Assessing risk aversion from the investor's point of view. Frontiers in Psychology 10:1490. https://doi.org/10.3389/ fpsyg.2019.01490.

Fauziah A. 2019. Penghindaran Risiko, Literasi Keuangan, dan Modal Sosial dalam Keputusan Investasi Saham Investor Pemula Pelajar Indonesia [tesis]. Bogor: Sekolah Program Pascasarjana, Institut Pertanian Bogor.

Grable JE, Carr NA. 2014. Risk tolerance and goalbased financial planning. Journal of Financial Service Professionals 68(1): 12-14.

Hakim A. 2010. Statistika Deskriptif untuk Ekonomi \& Bisnis. Yogyakarta : Ekonisia.

Hofmeyr A, Kincaid H. 2018. Prospect theory in the wild: how good is the nonexperimental evidence for prospect theory? Journal of Economic Methodology 26(1):13-31. https://doi.org/10.10 80/1350178X.2018.1561072.

Ilut CL, Schneider M. 2014. Ambiguous business cycles. American Economic Review 104(8): 2368-2399. https://doi.org/10.1257/aer.104.8.2368.

Kahneman D, Tversky A. 1979. Prospect theory: An analysis of decision under risk. Econometrica 47(2): 263-291. https://doi. org/10.2307/1914185.

Kapoora S, Prosad JM. 2017. Behavioural finance: a review. Procedia Computer Science 122: 50-54. https://doi.org/10.1016/j.procs.2017.11.340.

Lancaster GA, Dodd S, Williamson PR. 2004. Design and analysis of pilot studies: recommendations for good practice. Journal of Evaluation in Clinical Practice 10(2): 307-312. https://doi. org/10.1111/j..2002.384.doc.x.

Lee CJ, Andrade EB. 2015. Fear, excitement, and financial risk-taking. Cognition and Emotion. 29(1):178-187. https://doi.org/10.1080/0269993 1.2014.898611.

Lewandowski M. 2017. Prospect Theory Versus Expected Utility Theory: Assumptions, Predictions, Intuition and Modelling of Risk Attitudes. Central European JournalofEconomic Modelling and Econometrics 9: 275-321.

Liu YY, NacherJC, Ochiai T, Martino M, Altshuler Y. 2014. Prospect theory for online financial trading. PLoS ONE 9(10): e109458. https://doi. org/10.1371/journal.pone.0109458.

Mahdzan NS, Mohd-Any AA, Chan M. 2017. The influence of financial literacy, risk aversion and expectations on retirement planning and portfolio allocation in Malaysia. Gadjah Mada International Journal of Business 19(3): 267288. https://doi.org/10.22146/gamaijb.24441.

Pallant J. 2007. SPSS Survival Manual: A Step by Step Guide to Data Analysis Using SPSS for Windows. Ed. ke-3. Berkshire : McGraw-Hill and Open University Press.

Rasheed MH, Rafique A, Zahid T, Akhtar MW. 2018. Factors influencing investor's decision making in Pakistan: moderating the role of locus of control. Review of Behavioral Finance 10(1): 70-87. https://doi.org/10.1108/RBF-05-2016-0028.

Raut RK, Kumar R. 2018. Investment decisionmaking process between different groups of investors: A study of indian stock market. Asia-Pacific Journal of Management Research and Innovation 14(1-2): 39-49. https://doi. org/10.1177/2319510X18813770.

Robiyanto, Puryandani S. 2015. The javanese lunar calendar's effect on indonesian stock returns. Gadjah Mada International Journal of Business 17(2): 125-137. https://doi.org/10.22146/ 
gamaijb.6906.

Sauner J-B, Leroy. 2004. Managers and productive investment decisions: The impact of uncertainty and risk aversion. Journal of Small Business Management 42(1): 1-18. https://doi. org/10.1111/j.1540-627X.2004.00094.x.

Sobolev D, Chan B, Harvey N. 2017. Buy, sell, or hold? a sense-making account of factors influencing trading decisions. Cogent Economics \& Finance 5: 1-21. https://doi.org/10.1080/23322039.2017. 1295618.

Sugiyono. 2011. Metode Penelitian Kuantitatif, Kualitatif dan $R \& D$. Bandung: Afabeta.
Thaler RH. 1999. Mental accounting matters. Journal of Behavioral Decision Making 12(3): 183-206.

Tversky A, Kahneman D. 1992. Advances in prospect theory: Cumulative representation of uncertainty. Journal of Risk and Uncertainty 5:297-323. https://doi.org/10.1007/BF00122574.

Zahera SA, Bansal R. 2018. Do investors exhibit behavioral biases in investment decision making? A systematic review. Qualitative Research in Financial Markets 10(2): 210-251. https://doi. org/10.1108/QRFM-04-2017-0028. 